\author{
Jacek Michalski, Wojciech Sąsiadek, Kamil Owsiany \\ Uniwersytet Ekonomiczny we Wrocławiu \\ e-mails: jacek.michalski@ue.wroc.pl, ORCID: 0000-0001-5393-2109; \\ wojciech.sasiadek@ue.wroc.pl, ORCID: 0000-0001-6927-6759 \\ kamil.owsiany@gmail.com
}

\title{
CHARAKTERYSTYKA WYBRANYCH ZWIĄZKÓW CHEMICZNYCH ODPOWIEDZIALNYCH ZA CECHY ORGANOLEPTYCZNE PIWA
}

\section{CHARACTERISTICS OF SELECTED CHEMICAL COMPOUNDS RESPONSIBLE FOR THE ORGANOLEPTIC CHARACTERISTICS OF BEER}

DOI: $10.15611 /$ pn.2018.542.08

JEL Classification: Q19, I19, L66

Streszczenie: Celem pracy była charakterystyka najważniejszych związków chemicznych występujących w piwach, odpowiedzialnych za poszczególne doznania organoleptyczne. Ocena sensoryczna odbywa się z użyciem prawie wszystkich zmysłów. Oprócz oczywistych - smaku i węchu, słuch i wzrok również pozwalają na określenie jakości oraz świeżości piwa. Artykuł powstał na podstawie analizy różnych materiałów, tj. publikacji naukowych, czasopism branżowych oraz źródeł internetowych. Praca ma charakter opisowy i stanowi zbiór informacji z różnych dziedzin nauki, takich jak inżynieria procesowa, biotechnologia oraz nauki chemiczne. W opracowaniu zostały zamieszczone podstawowe informacje na temat tego, czym jest piwo, a także krótkie opisy podstawowych surowców produkcyjnych. Ponadto zaprezentowano najistotniejsze pojęcia dotyczące biochemii piwa, z charakterystyką poszczególnych związków chemicznych i wrażeń sensorycznych. Zostały one podzielone na surowce, z których pochodzą, i procesy produkcyjne, podczas których mogły powstać. W ostatniej części opracowania zawarto podsumowanie i wnioski.

Słowa kluczowe: piwo, związki chemiczne w piwie, ocena organoleptyczna.

Summary: The purpose of the paper is to characterize the most important chemical compounds present in beers, which are responsible for particular organoleptic sensations. Sensory evaluation takes place using almost all senses. In addition to the obvious taste and smell, hearing and sight also determine the quality and freshness of beer. The text was based on the analysis of various materials, ie: scientific publications, industry magazines and online sources. The article is descriptive and is a collection of information from various fields of science such as process engineering, biotechnology and chemical sciences. The paper contains basic information on what beer is, as well as short descriptions of the basic production raw materials. In addition, the article deals with the most important concepts 
related to beer biochemistry, with the characteristics of individual chemical compounds and sensory impressions. They were divided into raw materials from which they came and production processes during which they could be created. In the last part of this study there is a summary of the article and conclusions.

Keywords: beer, chemical compounds in beer, organoleptic evaluation.

\section{Wstęp}

Piwo towarzyszyło ludzkości niemal od czasów zakładania pierwszych osad i rozpoczęcia hodowli roślin zbożowych. Sumerowie jako pierwsi zaczęli klasyfikować piwo, które służyło już nie tylko jako napitek, lecz również lekarstwo, ofiara, a nawet waluta [Mosher 2004, s. 8-9].

Jednym z pierwszych i najważniejszych norm regulujących rodzaj surowców, produkcję oraz sprzedaż piwa było Niemieckie Prawo Czystości „Reinheitsgebot” z XVI w., zgodnie z którym jedynymi surowcami stosowanymi w wytwarzaniu piwa powinny być woda, słód i chmiel [Kunze 1999, s. XXI-XXII].

Amerykańska rewolucja piwowarska, charakteryzująca się próbą tworzenia nowych styli w piwowarstwie, stała się fundamentem powstania w 1985 r. Beer Judge Certification Program - BJCP, organizacji zrzeszającej piwowarów, początkowo przemysłowych, później także domowych, mającej na celu usystematyzowanie gatunków piw oraz ustalenie wytycznych, którym piwo musi odpowiadać, aby mogło do danego stylu należeć. Organizacja ta zrzesza ludzi zajmujących się wieloma dziedzinami nauki, m.in. mikrobiologią, chemią, inżynierią oraz technologią żywności [BJCP]. Polskim odpowiednikiem jest Polskie Stowarzyszenie Piwowarów Domowych - PSPD, organizujące konkursy piw domowych w Polsce, jak również zajmujące się certyfikacją sędziów i klasyfikacją styli dla Konkursu Piw Rzemieślniczych [PSPD].

\section{Charakterystyka podstawowych składników piwa}

\subsection{Woda}

Jest to najważniejszy składnik piwa, pierwszy pod względem ilościowym, jednak tylko część wody zużywanej podczas produkcji jest składnikiem piwa. Duża część browarów posiada własne studnie i stacje uzdatniania, by zapewnić kluczową dla produkcji jakość wody. Woda powinna spełniać aktualne normy wody pitnej ustanowione przez Ministerstwo Zdrowia i Opieki Społecznej, powinna być więc przede wszystkim pozbawiona drobnoustrojów chorobotwórczych oraz mogących utrudnić drożdżom piwowarskim przeprowadzenie fermentacji alkoholowej. Bardzo dużą rolę w produkcji piwa odgrywają odczyn $\mathrm{pH}$ oraz twardość ogólna wody. Jej składowymi są twardość węglanowa wywoływana przez obecność jonów wodorowęglano- 
wych $\mathrm{HCO}_{3}^{-}$i węglanowych $\mathrm{CO}_{3}^{2-}$, natomiast twardość niewęglanowa jest efektem obecności w wodzie jonów wapnia $\mathrm{Ca}^{2+}$ i magnezu $\mathrm{Mg}^{2+}$. Jako czynnik decydujący o tym, czy pH powinno być podniesione, czy obniżone, stosuje się wartość alkaliczności resztkowej wyrażanej w stopniach niemieckich $\left({ }^{\circ} \mathrm{n}\right)$ [Kunze 1999, s. 36-46].

\subsection{Slody}

Możliwe jest zastosowanie prawie każdego zboża jako surowca piwowarskiego. Przyjęło się jednak, że podstawowym surowcem do produkcji słodu jest jęczmień (Holderum vulgare L.) ze względu na dużą zawartość skrobi oraz stale przyłączoną do ziarna łuskę, która służy jako warstwa filtracyjna po procesie zacierania [Kunze 1999, s. 2]. Poza źródłem cukrów fermentowalnych, słód dostarcza do piwa także białka, tłuszcze oraz witaminy. Białka, betaglukany oraz dwutlenek węgla są później odpowiedzialne za tworzenie piany w piwie podczas nalewania gotowego piwa [Mosher 2009, s. 105-110].

\subsection{Chmiel i inne przyprawy}

Chmiel nie jest niezbędny do tego, by uzyskać dobry jakościowo produkt. Potocznie nazywane szyszki chmielu są w rzeczywistości żeńskimi kwiatostanami chmielu zwyczajnego (Humulus lupulus L.). Chmiel wnosi do piwa przede wszystkim gorzkie żywice, lupulinę oraz olejki eteryczne [Kunze 1999, s. 18-19].

Do uzyskania odpowiedniej goryczki należy chmiel dodać do gotującej się brzeczki w celu izomeryzacji $\alpha$-kwasów do rozpuszczalnych w wodzie izo- $\alpha$-kwasów [Lehrl 2013, s. 28].

Innym sposobem przyprawiania piwa jest stosowanie różnych mieszanek przypraw. Najbardziej popularną $\mathrm{z}$ nich jest gruit, stosowany w średniowieczu jeszcze przed rozpowszechnieniem chmielu. Innymi dodatkami mogą być przyprawy korzenne, zioła, owoce i ich skórki, a nawet gałązki roślin iglastych i kory brzozy. Popularne jest też dodawanie miodu, kupażowanie oraz sezonowanie piwa w beczkach drewnianych, często wykorzystanych wcześniej do produkcji innych alkoholi, np. whisky lub sherry [Mosher 2004, s. 158-164].

\subsection{Drożdże}

Główną rolą drożdży w piwowarstwie jest przeprowadzenie fermentacji alkoholowej z wykorzystaniem cukrów zawartych w brzeczce, w szczególności maltozy. Efektem tego są piwa o zawartości alkoholu od ok. 1\% objętościowo do nawet ok. $15 \%$ zawartości alkoholu objętościowo. Maltoza początkowo jest hydrolizowana do dwóch cząsteczek glukozy z wykorzystaniem maltazy, enzymu zawartego w drożdżach (rys. 1).

Glukoza jest później przekształcana na alkohol etylowy oraz dwutlenek węgla na drodze fermentacji alkoholowej, której przybliżony przebieg przedstawia poniższa reakcja (rys. 2) [Kunze 1999, s. 54]. 


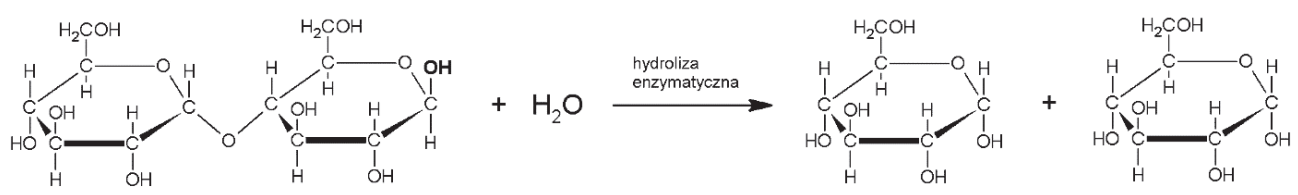

$\alpha$-maltoza

o-D-glukoza

Rys. 1. Hydroliza enzymatyczna maltozy

Źródło: [Stryer 1999].
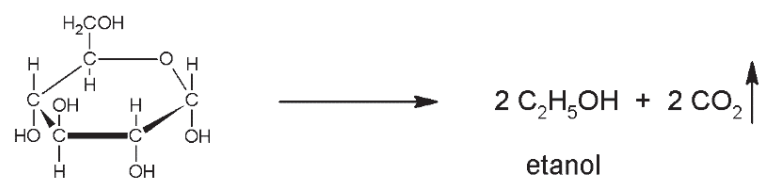

$\alpha$-D-glukoza

Rys. 2. Fermentacja alkoholowa

Źródło: [Stryer 1999].

W piwowarstwie wyróżnia się trzy główne typy drożdży:

- drożdże fermentacji dolnej - Saccaromyces carlsbergensis, tzw. lagerowe, zdolne do fermentacji w temperaturze ok. $4-10^{\circ} \mathrm{C}(277-283 \mathrm{~K})$,

- drożdże fermentacji górnej - Saccharomyces cerevisae (rys. 3), fermentujące w temperaturze ok. $15-20^{\circ} \mathrm{C}(288-293 \mathrm{~K})$,

- drożdże fermentacji spontanicznej - najczęściej używane w belgijskich stylach piw. Tradycyjnie po zakończeniu gotowania brzeczki i jej schłodzeniu wystawiało się ją na działanie otwartego powietrza.

\section{Biochemia piwa}

Odczucia sensoryczne odbierane przez zmysły chemiczne (smak i zapach) są wywoływane przez różne związki chemiczne. Bodźce są przetwarzane w mózgu, wywołując odczucie. Dużą rolę odgrywają emocje i pamięć, można bowiem wrażenie odbierać jako przyjemne bądź nie. Podświadomie też porównujemy odczucie ze wspomnieniami, dlatego czując jakąś cząsteczkę, kojarzymy ją z inną substancją. Dobrym przykładem jest diacetyl, który jest odpowiedzialny za maślany zapach piwa, jednak jest to tylko nasze skojarzenie z zapachem masła, który znamy z przeszłości. Smak i węch są głównymi zmysłami używanymi podczas oceny piwa. Pozostałe zmysły, jak wzrok, słuch i czucie, są zmysłami fizycznymi, wrażenia odbierane przez nie są bodźcami elektromagnetycznymi, akustycznymi, mechanicznymi lub związanymi z odczuwaniem ciepła. Należy jednak pamiętać, że zjawisko może 
być wywołane obecnością jakiejś cząsteczki, jednak nie musi być odbierane na drodze bodźca chemicznego. Przykładem może być obecność skrobi w piwie, która jest zauważalna zmysłem wzroku jako zmętnienie piwa. Inne związki mogą być odbierane więcej niż jednym zmysłem, czego przykładem jest dwutlenek węgla, który można zaobserwować jako bąbelki w piwie lub zmysłem dotyku jako odczucie szczypania w ustach [Gawęcki, Baryłko-Pikielna (red.) 2007, s. 14].

\subsection{Slody i surowce nieslodowane}

\section{Skrobia}

Źródłem skrobi w piwie jest ziarno. Jest ona głównym źródłem cukrów fermentujących w brzeczce. Podczas zacierania cała skrobia powinna zostać przekształcona $\mathrm{w}$ prostsze disacharydy i monosacharydy. Służą do tego zawarte w słodowanym ziarnie enzymy $\alpha$-amylaza oraz $\beta$-amylaza aktywowane poprzez podgrzewanie zacieru. Przerwa $\beta$-amylazowa zaczynająca się w temperaturze $62^{\circ} \mathrm{C}(335 \mathrm{~K})$ pozwala na uzyskanie dużej ilości łatwo dostępnych dla drożdży cukrów. $\alpha$-Amylaza aktywowana $\mathrm{w} 72^{\circ} \mathrm{C}(345 \mathrm{~K})$ odpowiada za scukrzenie pozostałej w brzeczce skrobi. Obecność tego polisacharydu jest niepożądana w żadnym z piwnych styli, gdyż powoduje mocne zmętnienie piwa oraz znaczne skrócenie terminu przydatności do spożycia produktu [Lehrl 2013, s. 56-59].

\section{Mono- i polisacharydy}

Mono- i polisacharydy w piwach pochodzą z hydrolizy skrobi. Część jest przekształcana podczas fermentacji na alkohol etylowy i dwutlenek węgla, są to przede wszystkim glukoza, maltoza, częściowo maltotrioza. Inne węglowodany, takie jak dekstryny, nie fermentują, pozostawiając jednak w piwie słodki smak. Ich stężenie w gotowym piwie zależne jest od stylu, w jakim jest uwarzone. Na podstawie stężenia cukrów w brzeczce początkowej określa się ekstrakt piwa, który jest ważną informacją na temat jego przyszłej zawartości alkoholu oraz poziomu słodyczy [Mosher 2004, s. 18-19].

\section{Związki dymu wędzarniczego}

Wędzenie słodu miało na początku na celu jego zakonserwowanie oraz było efektem ubocznym suszenia go gorącym powietrzem z paleniska, obecnie jednak jest to popularna metoda na zmianę jego walorów organoleptycznych. Najczęściej do tego celu używa się drewna dębu (Quercus L.), buku (Fagus L.) oraz torfu, jak w szkockim stylu wee heavy. Dym jest koloidalną mieszaniną powietrza, pary wodnej oraz produktów niepełnego spalenia paliwa. Najbardziej czynnymi substancjami dymu są fenole (gwajakol, syringol) i ich pochodne, związki karbonylowe, takie jak aldehydy (formaldehyd) i ketony, kwasy organiczne, alkohole, estry, etery oraz tlenki węgla $\left(\mathrm{CO}\right.$ i $\left.\mathrm{CO}_{2}\right)$. W gotowym piwie te substancje dają się odczuć jako zapach wędzonego mięsa lub sera oraz woń ogniska [Tkacz 2012, s. 14-15]. 


\section{Reakcje Maillarda}

Zarówno reakcje Maillarda, jak i karmelizacji to procesy odpowiedzialne za nieenzymatyczne brązowienie żywności. Jeśli ogrzewaniu poddaje się cukry, to powstają w ich wyniku karmele, powodujące m.in. zaciemnienie skórki chleba i wyrobów cukierniczych. W piwie są odpowiedzialne za jego barwę, karmelowy posmak, zapach chleba. Reakcja Maillarda to natomiast seria reakcji pomiędzy grupami karbonylowymi węglowodanów oraz grupami aminowymi aminokwasów. Powstaje w ten sposób wiele związków smakowo-zapachowych, w tym hydroksymetylofurfural i furfural (rys. 3). Tworzą się również substancje barwiące, melanoidyny.

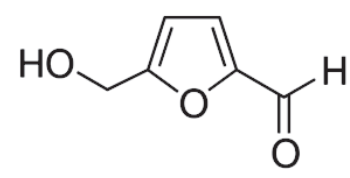

Hydroksymetylofurfural

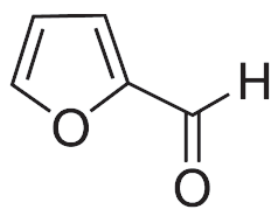

Furfural

Rys. 3. Główne produkty reakcji Maillarda: hydroksymetylofurfural i furfural Źródło: [Stryer 1999].

Związki barwiące zawarte w słodach, pochodzące z reakcji Maillarda i karmelizacji, przenikają do brzeczki podczas zacierania, co pozwala na uzyskanie szerokiej palety barw piwnych styli [Mosher 2004, s. 42-46].

\section{Białka}

Są obecne w każdym piwie i zauważalne przede wszystkim w formie piany oraz poprzez zmętnienie, które jest cechą szczególną piw pszenicznych i żytnich. W komercyjnych piwach dąży się do uzyskania jak najbardziej klarownej barwy piwa. Stosuje się w tym celu filtrację oraz klarowanie piwa żelatyną, mchem irlandzkim lub karukiem, czyli ekstraktem z pęcherzy pławnych ryb jesiotrowatych [Mosher 2009, s. 74]. Piana w piwie jest układem koloidalnym, w którym białka zamykają $\mathrm{w}$ przestrzennej siatce pęcherzyki $\mathrm{CO}_{2}$. Sztywna, długotrwała oraz oblepiająca szkło piana jest jednym z wyróżników poprawnie uwarzonego piwa. Większość piw ma w swoim składzie gluten składający się z gliadyn, glutenin, albumin i globulin [Sikorski (red.) 2012, s. 239-240].

\section{Siarczek dimetylu (DMS)}

Najczęściej uważany za wadę piwa siarczek pojawia się w brzeczce podczas gotowania. Ma zapach gotowanych warzyw, kukurydzy, kapusty, a w ciemnych piwach ketchupu i pomidorów [Mosher 2009, s. 53].

\section{Garbniki}

Inaczej zwane taninami, polifenole naturalnie występujące $\mathrm{w}$ chmielu oraz w jęczmieniu browarniczym w łusce ziarna. W piwach mogą występować w wyniku prze- 
grzania brzeczki na końcu zacierania oraz podczas filtracji, co wzmaga przenikanie tanin do brzeczki. Efektem tego jest często nieprzyjemne wrażenie ściągania śluzówki jamy ustnej oraz języka, co jest spowodowane denaturacją białek przez taniny [Bamforth 2003, s. 135].

\subsection{Chmiel i inne przyprawy}

\section{Olejki chmielowe}

$\mathrm{Na}$ aromat chmielu składają się setki lotnych związków chemicznych odpowiedzialnych za tak szeroki wachlarz aromatów. Piwowar może dobrać odpowiednie odmiany chmieli do uzyskania najlepszego efektu. Najważniejszymi składnikami olejów eterycznych są (rys. 4) [Baranowski 2014, s. 17]:

- myrcen, zapach piżma lub mchu<smiles>C=CC(=C)CCC=C(C)C</smiles>

Myrcen

- limonen, pachnący cytrusami, owocami tropikalnymi<smiles>C=C(C)C1CC=C(C)CC1</smiles>

(S)-Limonen

- geraniol, nerol, humulen, kariofilen, linalol, $\alpha$-terpineol, odpowiadają za aromaty kwiatowe<smiles>CC(C)=CCC/C(C)=C\CO</smiles>

Nerol

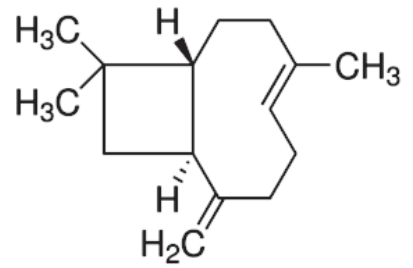

$\beta$-Kariofilen

- $\quad$ seskwiterpeny, gorzki smak i zapach żywicy 
- nerolidol, aromat pomarańczy<smiles>C=CC(C)(O)CCC=C(C)CCC=C(C)C</smiles>

Nerolidol

Rys. 4. Olejki eteryczne zawarte w chmielu

Źródło: [Stryer 1999].

- związki siarki,

- tiole,

- inne związki organiczne, takie jak aldehydy, ketony i estry.

\section{Goryczka}

Gorycz jest smakiem, który stał się jedną z głównych cech piwa i jego domeną. Obecnie pochodzi on od zizomeryzowanych postaci $\alpha$-kwasów zawartych $w$ żeńskich kwiatostanach chmielu. Międzynarodową formą ustalenia poziomu goryczy w piwie jest IBU (International Bittering Units), będący skalą od 1 do 120, z czego 1 IBU odpowiada $1 \mathrm{mg}$ izo- $\alpha$-kwasów rozpuszczonych w $1 \mathrm{dm}^{3}$ piwa. Skala IBU jest pomocna $\mathrm{W}$ określaniu zgodności piwa $\mathrm{z}$ danym stylem (rys. 5) [Suliga 2012, s. 28-32].

\subsection{Drożdże, fermentacja i kondycjonowanie}

\section{Dwutlenek węgla}

Dwutlenek węgla $\mathrm{CO}_{2}$ jest odpowiedzialny w piwie za tworzenie piany oraz tworzenie bąbelków widocznych po przelaniu piwa do szklanki, wyczuwalny jako szczypanie w jamie ustnej. Style piwne różnią się diametralnie poziomem nagazowania - od angielskich ale z ledwo wyczuwalnym szczypaniem w język do polskiego grodziskiego i innych piw pszenicznych, których nieumiejętne nalewanie może doprowadzić do zbytniego spienienia się piwa. Zawartość dwutlenku węgla w piwie waha się od 1500 do $4000 \mathrm{mg} / \mathrm{dm}^{3}$ [Kunze 1999, s. 330-333].

\section{Alkohol etylowy}

Produkowany jest przez drożdże wraz $\mathrm{z} \mathrm{CO}_{2}$ na drodze fermentacji alkoholowej z wykorzystaniem cukrów. Obecny w każdym piwie, w różnych stężeniach, od $0,5 \%$ obj. (poniżej tej wartości piwa określa się jako bezalkoholowe) do nawet 67,5 obj., co jest możliwe przez wielokrotne zamrażanie piwa i odbieranie wody w postaci lodu, co zatęża ilość alkoholu [Suliga 2017, s. 31-33]. Drożdże piwowarskie są w stanie dofermentować piwo nawet powyżej 20\% obj. (rys. 6). Etanol 
ma swoisty zapach oraz wywołuje odczucia od delikatnego rozgrzewania gardła do nieprzyjemnego pieczenia w wyższych stężeniach [Mosher 2009, s. 58; Kunze 1999, s. 300-304].

\section{Alkohole wyższe/fuzle}

Należą do niekorzystnych produktów ubocznych fermentacji alkoholowej. Występują w piwach młodych. Wyczuwalne szczególnie po ogrzaniu się piwa. Są to przede wszystkim (rys. 5) [Mosher 2009, s. 58]:

2-fenyloetanol, pachnący różami, pozostałe mają ostry zapach alkoholu
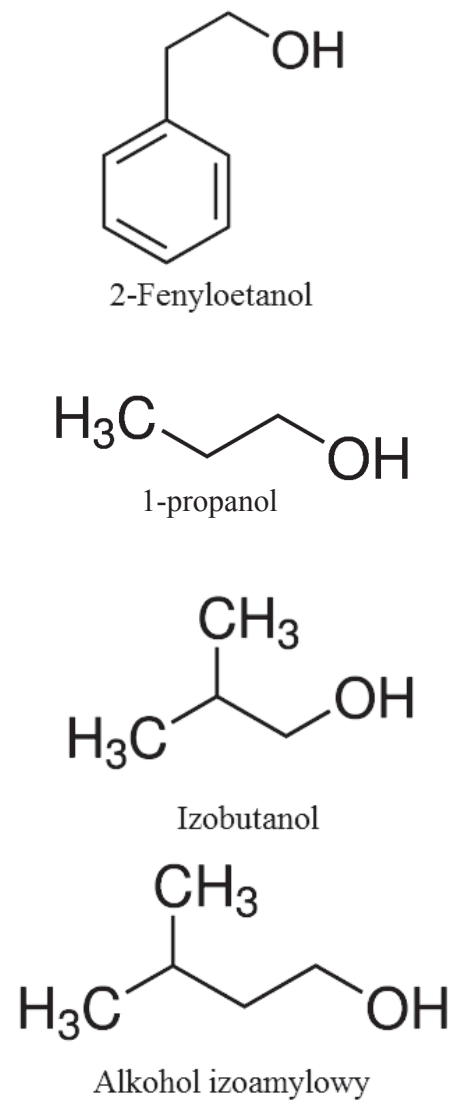

Rys. 5. Wyższe alkohole obecne w piwach

Źródło: [Stryer 1999].

\section{Diacetyl}

Jest jednym z najważniejszych składowych tworzących aromat piwa, szczególnie młodego (rys. 6). Łatwo wykrywalny, nawet przez niedoświadczonych degustatorów. Ma zapach masła, śmietany lub popcornu. Pożądany szczególnie w ciemnych angielskich stylach (bitter, dry stout) i czeskich lagerach, gdzie jest wyznacznikiem 
świeżości piwa. W pozostałych stylach akceptowalny w małych ilościach lub całkowicie nieakceptowalny. Normalna zawartość diacetylu w piwie to ok. $0,1 \mathrm{mg} / \mathrm{dm}^{3}$, próg wyczuwalności wynosi 0,1-0,15 mg/dm ${ }^{3}$ [Kunze 1999, s. 310-312].

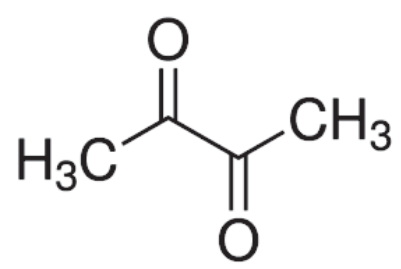

\section{Diacetyl}

Rys. 6. Wzór diacetylu

Źródło: [Stryer 1999].

\section{Kwas kaprylowy}

Opisywany jako aromat wosku, kozi, tłuszczu, łoju (rys. 7). Produkowany przez drożdże podczas leżakowania piwa. Często pożądany w belgijskich piwach dzikiej fermentacji lub w jasnych lagerach. W pozostałych stylach uważany za wadę. Typowe stężenie $\mathrm{w}$ piwie to $2-8 \mathrm{mg} / \mathrm{dm}^{3}$, przy progu wyczuwalności wynoszącym 4-6 mg/dm³ [Leszczyński 2014, s. 13].

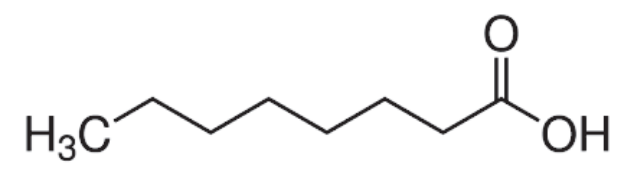

Kwas kaprylowy

Rys. 7. Wzór kwasu kaprylowego

Źródło: [Stryer 1999].

\section{Merkaptany}

Tiole, czyli alkohole, w których grupa -OH została zastąpiona grupą -SH. Niepożądane w żadnym ze styli. Merkaptan prenylowy określany jest świetlnym aromatem piwa, gdyż powstaje podczas naświetlenia produktu w wyniku stosowania nieodpowiednich opakowań (bezbarwnych butelek). Ma zapach skunksa, marihuany, nikotyny, siana. Merkaptan etylowy natomiast jest zapachem przywodzącym na myśl kanalizację, gaz ziemny, warzywa cebulowe. Oznacza zakażenie piwa obcymi mikroorganizmami. Typowe stężenie tych związków w piwie to $0-0,5 \mu \mathrm{g} / \mathrm{dm}^{3}$. Próg wyczuwalności wynosi $1 \mu \mathrm{g} / \mathrm{dm}^{3}$ [Leszczyński 2014, s. 2]. 


\section{Kwasy cytrynowy i mlekowy}

Są odpowiedzialne za kwasowość piwa, ustalaną na ok. 4,2-4,5 pH, a w piwach typowo kwaśnych (lambiki, berliner weisse) nawet do $3 \mathrm{pH}$. Zbyt duża kwasowość piwa może być spowodowana zakażeniem bakteriami kwasu mlekowego, za dużą ilością słodu zakwaszającego w zasypie, wysokim nasyceniem $\mathrm{CO}_{2}$ Typowe stężenie dla kwasu cytrynowego to $90-300 \mathrm{mg} / \mathrm{dm}^{3}$, przy progu wyczuwalności wynoszącym $170 \mathrm{mg} / \mathrm{dm}^{3}$ (zob. rys. 8) [Leszczyński 2014, s. 5].

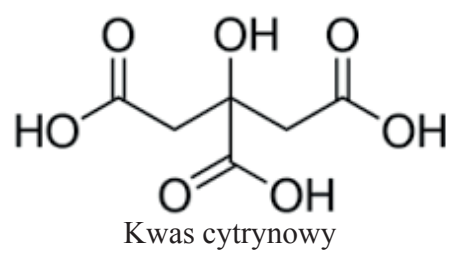

Rys. 8. Wzór kwasu cytrynowego

Źródło: [Stryer 1999].

\section{Fenole}

Występują w ziarnach i chmielu, są jednymi z ważniejszych substancji tworzących bukiet piwa. Popularne ze względu na swoje właściwości przeciwutleniające (rys. 9) [Klepacka, Fornal 2004, s. 6].

- 4-winylogwajakol - najczęściej określany jako fenolowy zapach w piwach pszenicznych. Jest to przyjemny zapach goździków [Mosher 2009, s. 56].

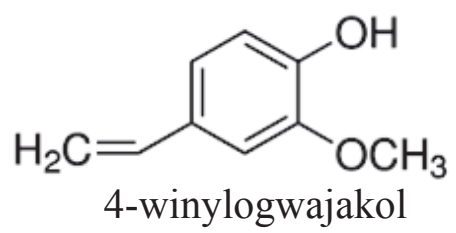

- chlorofenol - chemiczny zapach bandaży, apteki, może oznaczać niepoprawne przepłukanie instalacji po dezynfekcji środkami zawierającymi chlor [Mosher 2009, s. 60].<smiles>Oc1ccccc1Cl</smiles>

Rys. 9. Fenole obecne w piwach Źródło: [Stryer 1999]. 


\section{Estry}

Powstają podczas estryfikacji kwasów tłuszczowych i alkoholi wyższych. Obecne w każdym piwie w różnych stężeniach są najważniejszymi składnikami bukietu piwnego. W wyższych stężeniach mogą powodować uczucie nieprzyjemnej goryczy. Są mniej tolerowane w piwach fermentacji dolnej ze względu na czysty słodowy bukiet wymagany w tych stylach. Z kilkudziesięciu różnych związków najważniejsze to (rys. 10) [Kunze 1999, s. 313-314]:

- octan etylu, związany z zapachami owocowymi, landrynek<smiles>CCOC(C)=O</smiles>

Octan etylu

- octan izobutylu, aromat bananów<smiles>CC(=O)OCC(C)C</smiles>

Octan izobutylu

- octan izoamylu, aromat bananów<smiles>CC(=O)OCCC(C)C</smiles>

- maślan etylu, zapach jabłek, papai, mango, sera, ananasa<smiles>CCCC(=O)OCC</smiles>

- kapronian etylu, zapach czerwonych jabłek, anyżu<smiles>CCCCCC(=O)OCC</smiles> 
- dodekanian etylu, mydło, ,estrowy”

$$
\mathrm{CH}_{3}\left(\mathrm{CH}_{2}\right)_{9} \mathrm{CH}_{2} \stackrel{\mathrm{OCH}}{3}_{\mathrm{CH}_{3}}^{\mathrm{O}}
$$

Dodekanian etylu

- mleczan etylu, powstały przy zakwaszaniu biologicznym, aromat truskawki<smiles>CCOC(=O)C(C)O</smiles>

Mleczan etylu

- kaprylan etylu, dający aromat gruszki

$$
\mathrm{CH}_{3}\left(\mathrm{CH}_{2}\right)_{5} \mathrm{CH}_{2} \stackrel{\mathrm{O}}{\mathrm{CH}_{3}}
$$

Kaprylan etylu

Rys. 10. Estry obecne w piwach

Źródło: [Stryer 1999].

\section{Siarkowodór}

Znany powszechnie, może być niebezpieczny dla zdrowia. $\mathrm{H}_{2} \mathrm{~S}$ jest wytwarzany zawsze przez drożdże $\mathrm{w}$ trakcie fermentacji. W małych stężeniach wprowadza „świeżość" do piwa, w większych przywodzi na myśl zapach siarki i starych jaj. Jego wyczuwalność często oznacza zakażenie bakteryjne lub krótką fermentację [Leszczyński 2014, s. 6].

\section{Kwas butanowy}

Kwas butanowy (masłowy) (rys. 11) najczęściej kojarzony jest z zapachem zjełczałego tłuszczu, chorego dziecka, wymiotów, zgnilizny. Jest kwasem karboksylowym. Obecny w piwach zakażonych. Mimo odrzucającego zapachu, jego pochodne, jak np. maślan etylu, mogą pachnieć bardzo przyjemnie. Może być odczuwany jako gorzki smak. Typowe stężenie w gotowym produkcie: $0,5-1,5 \mathrm{mg} / \mathrm{dm}^{3}$, a próg wyczuwalności: 2-3 mg/dm³ [Leszczyński 2014, s. 7]. 


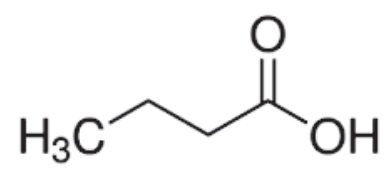

Kwas masłowy

Rys. 11. Wzór kwasu butanowego

Źródło: [Stryer 1999].

\section{Aldehyd octowy}

Kojarzony jest przede wszystkim z zapachem zielonego jabłka lub rozpuszczalnika, jest wyznacznikiem zbytniego natlenienia brzeczki podczas produkcji (rys. 12). Normalnie występuje w piwie w stężeniu $2-15 \mathrm{mg} / \mathrm{dm}^{3}$. Jest wyczuwalny przy $5-15 \mathrm{mg} / \mathrm{dm}^{3}$ [Kunze 1999, s. 312].

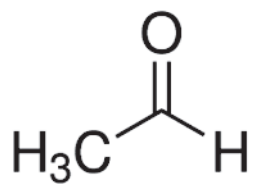

Aldehyd octowy

Rys. 12. Wzór aldehydu octowego

Źródło: [Stryer 1999].

\section{Kwas octowy}

W niskich stężeniach jest akceptowalny, wyczuwalny jako kwaśny smak (rys. 13). Zbyt duża ilość wskazuje na zakażenie piwa bakteriami Acetobacter. Może być obecny w większych stężeniach w piwach kwaśnych. Bardzo ważna cecha lambików i piw w stylach flanders [Mosher 2009, s. 57].

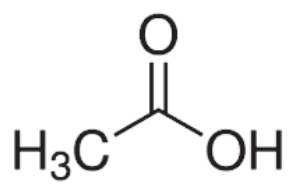

Kwas octowy

Rys. 13. Wzór kwasu octowego

Źródło: [Stryer 1999]. 


\section{p-Mentano-8-merkapto-3-on}

Uważany jest za wadę, z wyjątkiem niewielkiej liczby piw angielskich (rys. 14). Wywołuje zapach kociego moczu, czarnej porzeczki, kuwety, agrestu. Spowodowany jest utlenieniem się piwa, zakażeniem tlenkiem mezytylu, niewłaściwym przechowywaniem chmielu.<smiles>CC1CCC(C(C)(C)S)C(=O)C1</smiles>

p-Mentano-8-merkapto-3-on

Rys. 14. Wzór p-Mentano-8-merkapto-3-onu

Źródło: [Stryer 1999].

\section{Trichloroanizol, geosmina i 2-etylofenchol}

Odpowiedzialne są za spleśniały, ziemisty zapach porównywany również do zapachu korka (rys. 15). Obecne w piwach zamykanych z użyciem naturalnego korka lub zanieczyszczonych pleśniami [Mosher 2009, s. 60].<smiles>COc1c(Cl)cc(Cl)cc1Cl</smiles>

2,4,6-trichloroanizol

Rys. 15. Wzór 2,4,6-trichloroanizolu Źródło: [Stryer 1999].

\section{Podsumowanie}

Piwo towarzyszy ludziom od tysięcy lat. Obecnie jest jednym z najpopularniejszych napojów i najczęściej konsumowanym napojem alkoholowym. Zawartość takich składowych, jak: witaminy z grupy B, krzem i przeciwutleniacze czynią z niego dobre uzupełnienie diety.

Rewolucja piwna, mająca początek w USA już w latach 70., dotarła kilka lat temu także i do Polski. Na rynku pojawiły się nowe odmiany chmieli, nietypowe 
słody, specjalistyczny sprzęt i podręczniki pozwalające entuzjastom warzyć piwa domowe i startować z nimi w konkursach. Ciągle prowadzi się badania naukowe i przeprowadza się analizy sensoryczne pomagające w wykrywaniu związków chemicznych składających się na bukiet smakowo-zapachowy piw.

W miarę rozwoju rynku piwnego w Polsce i na świecie rozwija się także świadomość ludzi co do tego, jak skomplikowany w składzie jest to napój. Podczas paneli degustacyjnych można się dowiedzieć, dlaczego piwo jest gazowane, jakie związki chemiczne odpowiadają za dane doznania, a także jak odróżniać piwa od siebie podczas degustacji. Produkcja piwa łączy w sobie wiele gałęzi nauki: inżynierię chemiczną, biotechnologię, maszynoznawstwo, termodynamikę oraz ekonomię. Najważniejsze jest jednak to, że przestaje być to napój dostarczający tylko alkohol do organizmu, a zaczyna służyć jako narzędzie do edukacji ludzi na temat technik produkcji żywności oraz jej składu chemicznego.

Przedstawione $\mathrm{w}$ niniejszej pracy substancje odpowiedzialne za cechy organoleptyczne piwa stanowią z pewnością tylko część związków, dzięki którym konsumenci odczuwają różne style i gatunki piwne, a także je rozróżniają. Na walory użytkowe piwa wpływają także inne związki chemiczne, ich wzajemne proporcje oraz specyficzne interakcje zachodzące między nimi.

\section{Literatura}

Bamforth C., 2003, Beer: Tap into the Art and Science of Brewing, Oxford University Press, New York. Baranowski K., 2014, Zmiany w udziałach najważniejszych składników olejków chmielowych i ich wplyw na jakość aromatu chmielowego w piwach, Przemysł Fermentacyjny i Owocowo-Warzywny, nr 6, s. 28-32.

BJCP, Beer Judge Certification Program, www.bjcp.com.

Gawęcki J., Baryłko-Pikielna N., (red.) 2007, Zmysty a jakość żywności i żywienia, Akademia Rolnicza im. A. Cieszkowskiego w Poznaniu, Poznań.

Klepacka J., Fornal Ł., 2004, Związi fenolowe i ich wpływ na jakość piwa, Przemysł Fermentacyjny i Owocowo-Warzywny, nr 11, s. 6.

Kunze W., 1999, Technologia piwa i słodu, Piwochmiel, Warszawa.

Lehrl R., 2013, Domowe warzenie piwa, RM, Warszawa.

Leszczyński P., 2014, Opis cech sensorycznych piwa, PSPD, Warszawa.

Mosher R., 2004, Radical brewing, Brewers publications, Boulder.

Mosher R., 2009, Tasting beer, an insider's guide to the world's greatest drink, Storey, North Adams.

PSPD, Polskie Stowarzyszenie Piwowarów Domowych, www.pspd.org.pl.

Sikorski Z.E., (red.) 2012, Chemia żywności, t. 2, WNT, Warszawa.

Suliga M., 2012, Gorycz czy goryczka, Przemysł Fermentacyjny i Owocowo-Warzywny, nr 11-12, s. $28-32$.

Suliga M., 2017, Piwne rekordy, Przemysł Fermentacyjny i Owocowo-Warzywny, nr 7, s. 31-33.

Tkacz K., Więk A., 2012, Proces wędzenia, Gospodarka Mięsna, nr 10, s. 14-15. 